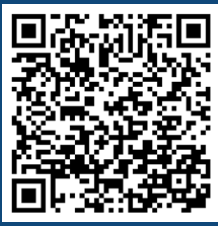

Keywords:

Fuzzy analytical hierarchy process

Multicriteria decision-making

Planing

Wood

Historic:

Received 17/08/2019

Accepted I I/02/2020

Correspondence: hilal.singer@hotmail.com
Hilal Singer ${ }^{\text {la+ }}$, Şükrü Özşahin ${ }^{2 a}$

\section{A MULTIPLE CRITERIA ANALYSIS OF FACTORS INFLUENCING SURFACE ROUGHNESS OF WOOD AND WOOD-BASED MATERIALS IN THE PLANING PROCESS}

SINGER, H.; ÖZŞAHIN, S. A multiple criteria analysis of factors influencing surface roughness of wood and wood-based materials in the planing process. CERNE, v. 26, n. I, p.58-65, 2020.

\section{HIGHLIGHTS}

Some factors influencing the surface roughness of wood and wood-based materials in the planing process are analyzed.

The FAHP method is proposed to determine the weights of the factors.

The most significant factors are feed speed, tool geometry, and material defect.

The findings of this study can be used in the wood industry to enhance product quality.

\section{ABSTRACT}

This paper presents a study of the fuzzy analytical hierarchy process (FAHP) for the prioritization of factors having important effects on the surface roughness of wood and wood-based materials in the planing process. Firstly, a three-level hierarchical model was devised. Secondly, the FAHP method was employed to determine the weights of the factors. Finally, the prioritization of the factors was carried out taking into account the weights. The results showed that the most significant factors are feed speed $(0.300)$, tool geometry $(0.222)$, and material defect $(0.107)$. Consequently, this study provides a valuable guide to the wood industry to improve the surface quality of wood and woodbased products. 


\section{INTRODUCTION}

Surface roughness can be defined as fine irregularities on a machined surface (Magoss, 2008). The surface roughness of wood influences further manufacturing processes such as joining application, bonding quality, and its strength characteristics, and the appearance of a final product (Kilic et al., 2006; Buyuksari et al., 20II; Li et al., 2017). However, the determination of surface roughness is a complex process owing to cutting processes, machining conditions, and the anatomical structure of wood (Malkoçoğlu, 2007). Although many roughness measurement methods (laser, light sectioning, pneumatic, stylus, etc.) are available, there is no accepted standard method to determine the surface roughness of wood and wood products. The stylus method has been successfully used in many studies (Tan et al., 20I2; Hiziroglu et al., 20I3; Ulker, 20I8).

Wood materials are processed through various steps, including planing, sawing, and sanding. The surface quality of wood subjected to machining is influenced by many factors related to wood characteristics and machining conditions (Pinkowski et al., 2018). The most significant factors related to the wood characteristics are wood species, anatomical properties, density, and moisture content (Aguilera, 20II; Ugulino and Hernández, 2017). In addition to these factors, process parameters such as cutting speed, cutting depth, feed speed, and tool geometry significantly affect the surface quality of wood (Lu, 2008; İşleyen and Karamanoğlu, 2019). To improve the surface quality of the final product, it is essential to have a basic knowledge of the factors related to both wood characteristics and machining conditions (Gurleyen, 2010).

Many researchers have evaluated the effects of various factors on the surface roughness of wood (Sütçü, 2013; Lopes et al., 20I4; Tiryaki et al., 20I5; Tiryaki et al., 2017). The studies in the related literature have revealed that the importance of each factor is different. Therefore, the determination of the importance of factors influencing the surface roughness of wood is necessary. Multicriteria decision-making (MCDM) methods can be used to obtain the priority values of main factors and subfactors. However, tangible and intangible factors cause vagueness and ambiguity in the decisionmaking process. The fuzzy set theory can convert human judgments into meaningful results. Therefore, in this study, the use of the fuzzy MCDM is preferred. The fuzzy analytical hierarchy process (FAHP) is the most popular fuzzy MCDM method. Prioritizing the factors by utilizing
FAHP yields supportive and logical results (Bozbura et al., 2007; Heo et al., 20 I0; Beşikçi et al., 2016).

The MCDM methods have been successfully employed in the field of wood science. Smith et al. (1995) employed the analytical hierarchy process (AHP) to analyze factors affecting the adoption of timber as a bridge material. Azizi (2008) selected the best wood supply alternative by employing the analytic network process (ANP) and the BOCR approach. Lipušček et al. (20l0) employed the AHP method to classify wood products in terms of their impact on the environment. Azizi and Modarres (20II) selected the best construction panel by using the AHP and ANP methods. Azizi et al. (20I2) used the AHP method to select the best medium density fiberboard (MDF) product. Kuzman and Grošelj (20I2) compared different construction types by utilizing the AHP method. Sarfi et al. (20/3) used the AHP method to analyze factors influencing the markets of particleboard and MDF. Karakuş et al. (2017) employed the technique for order preference by similarity to ideal solutions (TOPSIS), the multiple attribute utility theory (MAUT), and the compromise programming (CP) to predict the optimum properties of some nanocomposites.

There are many attempts on solving various decision-making problems in the field of wood science. However, a MCDM method has not yet been used to prioritize factors influencing the surface roughness of wood and wood-based materials in the planing process. Therefore, the objectives of this study are to determine the importance of each factor by employing the FAHP method and to provide a useful guide to the wood industry.

\section{MATERIAL AND METHODS}

\section{Fuzzy Sets and Fuzzy Numbers}

The fuzzy set theory was developed by Zadeh (1965) in order to represent the uncertainty, vagueness, and ambiguity of judgments (Lee et al., 20 I I). In a classical set, an element belongs to, or does not belong to, a set whereas an element of a fuzzy set naturally belongs to the set with a membership value from the interval $[0,1]$ (Kahraman and Kaya, 20I0).

The most commonly used fuzzy numbers are triangular and trapezoidal fuzzy numbers (Ebadi et al., 2013). In this study, triangular fuzzy numbers will be used to represent the linguistic terms due to their ease of calculation (Tsai and Chou, 20II). A triangular fuzzy number $\tilde{M}$ can be represented as $(I, m, u)$, and its membership function $\mu_{M}(x)$ can be given as follows (Büyüközkan and Çifçi, 20I2): 
$\mu_{M}(x)=\left\{\begin{array}{lr}0, & x<1 \text { or } x>u \\ (x-D) /(m-1), & 1 \leq x \leq m \\ (u-x) /(u-m), & m \leq x \leq u\end{array}\right\}$ where $\mid \leq m \leq u$.

Let $\widetilde{M}_{1}=\left(l_{1}, m_{1}, u_{1}\right)$ and $\tilde{M}_{2}=\left(l_{2}, m_{2}, u_{2}\right)$ be triangular

fuzzy numbers. The operations on these triangular fuzzy numbers are defined as follows (Lee et al., 20l I):

$\widetilde{M}_{1} \oplus \widetilde{M}_{2}=\left(l_{1}+I_{2}, m_{1}+m_{2}, u_{1}+u_{2}\right)$

$\widetilde{M}_{1} \otimes \widetilde{M}_{2}=\left(l_{1} / 2, m_{1} m_{2}, u_{1} u_{2}\right)$

$\widetilde{M}_{1}^{-1}=\left(1 / u_{1}, 1 / m_{1}, 1 / l_{1}\right)$

The triangular fuzzy conversion scale used in this study is given in Table I.

TABLE I The triangular fuzzy conversion scale.

\begin{tabular}{ccc}
\hline Linguistic scale & Triangular fuzzy scale & $\begin{array}{c}\text { Triangular fuzzy } \\
\text { reciprocal scale }\end{array}$ \\
\hline Absolutely important & $(9,9,9)$ & $(\mathrm{I} / 9, \mathrm{I} / 9, \mathrm{I} / 9)$ \\
Intermediate & $(7,8,9)$ & $(\mathrm{I} / 9, \mathrm{I} / 8, \mathrm{I} / 7)$ \\
Very strong & $(6,7,8)$ & $(\mathrm{I} / 8, \mathrm{I} / 7, \mathrm{I} / 6)$ \\
Intermediate & $(5,6,7)$ & $(\mathrm{I} / 7, \mathrm{I} / 6, \mathrm{I} / 5)$ \\
Strong & $(4,5,6)$ & $(\mathrm{I} / 6, \mathrm{I} / 5, \mathrm{I} / 4)$ \\
Intermediate & $(3,4,5)$ & $(\mathrm{I} / 5, \mathrm{I} / 4, \mathrm{I} / 3)$ \\
Weak & $(2,3,4)$ & $(\mathrm{I} / 4, \mathrm{I} / 3, \mathrm{I} / 2)$ \\
Intermediate & $(\mathrm{I}, 2,3)$ & $(\mathrm{I} / 3, \mathrm{I} / 2, \mathrm{I})$ \\
Equally important & $(\mathrm{I}, \mathrm{I}, \mathrm{I})$ & $(\mathrm{I}, \mathrm{I}, \mathrm{I})$ \\
\hline
\end{tabular}

\section{Fuzzy Analytical Hierarchy Process Method}

AHP is a useful method to solve complex MCDM problems involving multiple qualitative and quantitative criteria (Saaty, 1980). The AHP method breaks down a complex MCDM problem into a hierarchy of decision elements (see Figure I). To construct evaluation matrices, pairwise comparisons must be made by experts. Once pairwise comparison matrices are normalized, the rows of these matrices are averaged to determine the importance of each decision element. Moreover, the consistency ratio (CR) can be computed to check the consistency of judgments. If the $C R$ value exceeds 0.10 , the decision-maker must revise comparisons (Saaty, 1980; Işıklar and Büyüközkan, 2007; Rajak et al., 2016).

The traditional AHP method is based on crisp judgments. However, it is very difficult to acquire

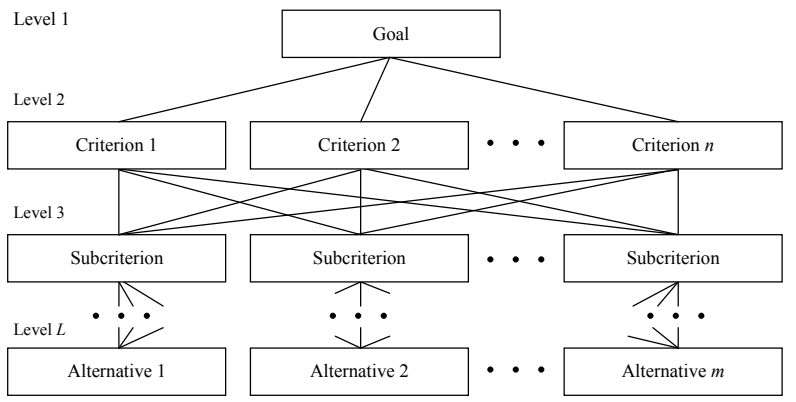

FIGURE I The general structure of AHP. precise data owing to the uncertainty on the judgments of decision-makers. Each decision-maker prefers natural language expressions rather than crisp numbers. In order to capture uncertainties, the FAHP method has been employed by several researchers (Heo et al., 20I0). There are various FAHP methods. Brief information about some FAHP methods can be found in Bozbura et al. (2007). In this study, Chang's extent analysis method (Chang, 1996) is used owing to its computational simplicity and effectiveness. The procedure of the FAHP approach is as follows (Bozbura et al., 2007; Beşikçi et al., 2016):

Step 1: The value of fuzzy synthetic extent with respect to the ith object is calculated using the following equation, where $M_{g_{j}}^{j}$ shows a triangular fuzzy number related to the $j$ th target.

$S_{i}=\sum_{j=1}^{m} M_{g_{1}}^{j} \otimes\left[\sum_{i=1}^{n} \sum_{j=1}^{m} M_{g_{1}}^{j}\right]^{-1}$

To obtain $\sum_{j=i}^{m} M_{g^{\prime} e^{\prime}}^{j}$, the fuzzy addition operation of $m$ extent analysis values is performed using Equation (6).

$\sum_{j=1}^{m} M_{g_{j}}^{j}=\left(\sum_{j=1}^{m} l_{j} \sum_{j=1}^{m} m_{j} \sum_{j=1}^{m} u_{j}\right)$

The fuzzy addition operation of $M_{g}^{j}(j=1,2, \ldots, m)$ values is performed to obtain .

$\left[\sum_{i=1}^{n} \sum_{j=1}^{m} M_{g_{l}}^{j}\right]^{-1}$.

$\sum_{i=1}^{n} \sum_{j=1}^{m} M_{g_{j}}^{j}=\left(\sum_{i=1}^{n} l_{j} \sum_{i=1}^{n} m_{i} \sum_{i=1}^{n} u_{i}\right)$

The inverse of the vector in Equation (8) is calculated using the following equation:

$\left[\sum_{j=1}^{n} \sum_{j=1}^{m} M_{g_{j}}^{j}\right]^{-1}=\left(\frac{1}{\sum_{i=1}^{n} u_{i}}, \frac{1}{\sum_{i=1}^{n} m_{i}}, \frac{1}{\sum_{j=1}^{n} l_{i}}\right)$

Step 2: The degree of possibility of 10 is defined as follows, where $d$ is the ordinate of the highest intersection point between ${ }^{\mu_{M_{1}}}$ and ${ }^{\mu_{M_{2}}}$ (see Figure 2).

$M_{2}=\left(l_{2}, m_{2}, u_{2}\right) \geq M_{1}=\left(l_{1}, m_{1}, u_{1}\right)$

$V\left(M_{2} \geq M_{1}\right)=\sup _{y z x}\left[\min \left(\mu_{M_{1}}(x), \mu_{M_{2}}(y)\right)\right]=\operatorname{hgt}\left(M_{1} \cap M_{2}\right)=\mu_{M_{2}}(d)$

$=\left\{\begin{array}{lr}1, & m_{2} \geq m \\ 0, & l_{1} \geq u_{2} \\ \frac{l_{1}-u_{2}}{\left(m_{2}-u_{2}\right)-\left(m_{1}-l_{1}\right)}, & \text { otherwise }\end{array}\right.$

In order to compare $M_{1}$ and $M_{2}$ the values of $V\left(M_{1} \geq M_{2}\right)$ and $V\left(M_{2} \geq M_{1}\right)$ are required.

Step 3: The degree of possibility for a convex fuzzy number to be greater than $k$ convex fuzzy numbers $M_{i}(i=1,2, \ldots, k)$ can be defined as follows: 


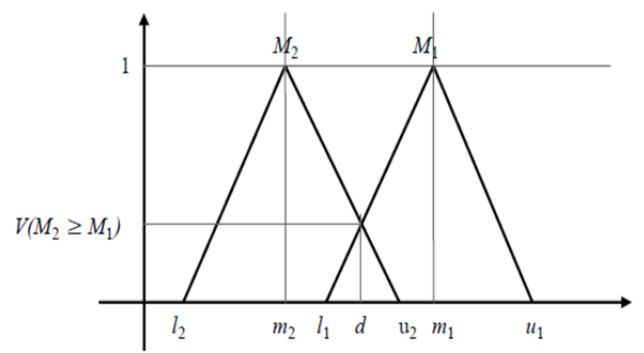

FIGURE 2 The intersection between $M_{2}$ and $M_{1}$

$V\left(M \geq M_{1}, M_{2}, \ldots, M_{k}\right)=V\left[\left(M \geq M_{1}\right)\right.$ and $\left(M \geq M_{2}\right)$ and $\ldots$ and $\left.\left(M \geq M_{k}\right)\right]$

$$
=\min V\left(M \geq M_{i}\right), i=1,2,3, \ldots, k .
$$

Assume that 13 for 14 . Then the weight vector is given by 15 where $A_{i}(i=1,2, \ldots, n)$ are $n$ elements.

$$
\begin{aligned}
& d^{\prime}\left(A_{j}\right)=\min V\left(S_{i} \geq S_{k}\right) \\
& k=1,2, \ldots, n ; k \neq i . \\
& W^{\prime}=\left(d^{\prime}\left(A_{1}\right), d^{\prime}\left(A_{2}\right), \ldots, d^{\prime}\left(A_{n}\right)\right)^{\top}
\end{aligned}
$$

Step 4: The normalized weight vector is obtained as below, where $W$ is a non-fuzzy number.

$$
W=\left(d\left(A_{1}\right), d\left(A_{2}\right), \ldots, d\left(A_{n}\right)\right)^{\top}
$$

\section{Fuzzy Analytical Hierarchy Process Analysis}

In this study, the FAHP method is used to determine the importance of some factors affecting the surface roughness of wood and wood-based materials in the planing process. The solution methodology adopted for this study is given in Figure 3.

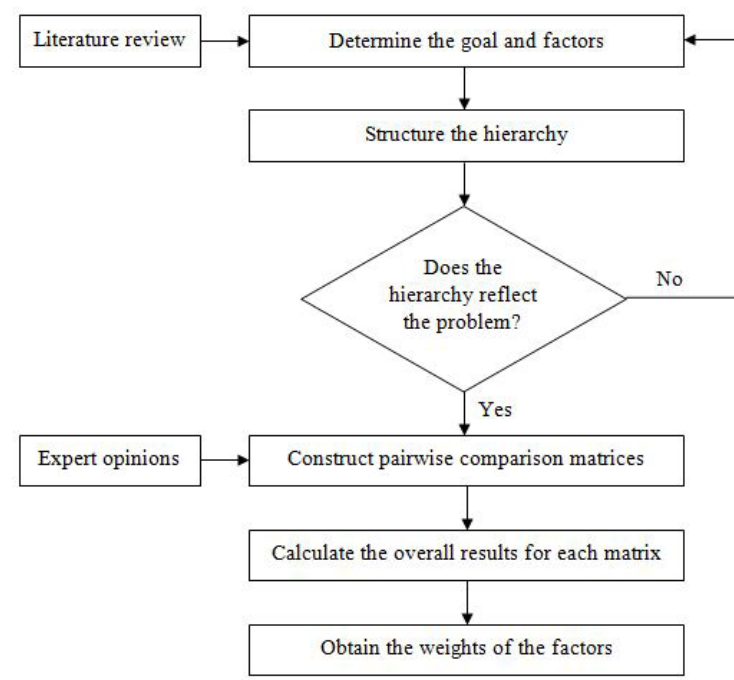

FIGURE 3 The flow chart of the research.

A three-level hierarchical model is devised to prioritize the factors. The research model is presented in Figure 4. As seen in this figure, the goal of the decisionmaking problem is placed at the highest level of the hierarchy. Moreover, there are four main factors at the second level and eighteen subfactors at the third level.

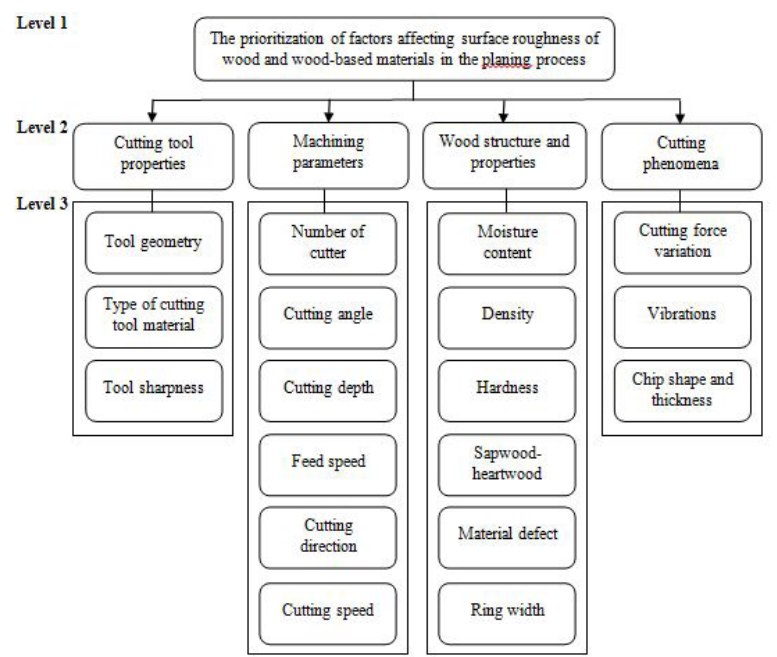

FIGURE 4 The hierarchical structure of the decisionmaking problem.

The main factors of this study are cutting tool properties $\left(F_{1}\right)$, machining parameters $\left(F_{2}\right)$, wood structure and properties $\left(\mathrm{F}_{3}\right)$, and cutting phenomena $\left(\mathrm{F}_{4}\right)$. The cutting tool properties factor includes three subfactors: tool geometry $\left(F_{11}\right)$, type of cutting tool material $\left(F_{12}\right)$, and tool sharpness $\left(F_{13}\right)$. The machining parameters factor consists of six subfactors: number of cutter $\left(F_{21}\right)$, cutting angle $\left(F_{22}\right)$, cutting depth $\left(F_{23}\right)$, feed speed $\left(\mathrm{F}_{24}\right)$, cutting direction $\left(\mathrm{F}_{25}\right)$, and cutting speed $\left(\mathrm{F}_{26}\right)$. The wood structure and properties factor is composed of six subfactors: moisture content $\left(F_{31}\right)$, density $\left(F_{32}\right)$, hardness $\left(F_{33}\right)$, sapwood-heartwood $\left(F_{34}\right)$, material defect $\left(F_{35}\right)$, and ring width $\left(F_{36}\right)$. Finally, the cutting phenomena factor includes three subfactors: cutting force variation $\left(F_{41}\right)$, vibrations $\left(F_{42}\right)$, and chip shape and thickness $\left(F_{43}\right)$.

After creating the hierarchical structure, the factors used in this study are assigned weights by using the FAHP method. This method employs pairwise comparisons to determine the importance of each decision element (Işılklar and Büyüközkan, 2007). Therefore, a decision-making team consisting of wood science experts is constructed. The experts of this study are academicians who have at least 10 years' experience on surface roughness.

A questionnaire is used to collect the data. The experts use the linguistic terms to make the pairwise comparisons of the factors. It is not possible to carry out arithmetical operations with the linguistic terms. Therefore, each linguistic term is associated with a triangular fuzzy number. The overall results are computed by taking the geometric mean of the individual evaluations. The final evaluation matrix of the main factors is given in Table 2. The calculation of the weights of the main factors will be explained below.

The values of fuzzy synthetic extents are calculated using Equation (5). 
TABLE 2 The comparison matrix of the main factors.

\begin{tabular}{|c|c|c|c|c|c|}
\hline Main factor & $\mathrm{FI}$ & F2 & F3 & F4 & Weight \\
\hline $\mathrm{FI}$ & $(1.000,1.000,1.000)$ & $(0.485,0.669,0.93 I)$ & $(0.855,1.170,1.682)$ & $(1.4 \mid 4,1.495,1.565)$ & 0.258 \\
\hline F2 & (1.075, I.495, 2.060) & $(1.000,1.000,1.000)$ & $(1.189,1.495,1.861)$ & $(1.682,2.340,2.913)$ & 0.491 \\
\hline $\mathrm{F} 3$ & $(0.595,0.855, \mathrm{I} .170)$ & $(0.537,0.669,0.84 I)$ & $(1.000,1.000,1.000)$ & $(1.189,1.682,2.178)$ & 0.251 \\
\hline F4 & $(0.639,0.669,0.707)$ & $(0.343,0.427,0.595)$ & $(0.459,0.595,0.841)$ & $(1.000,1.000,1.000)$ & 0.000 \\
\hline
\end{tabular}

$S_{F_{1}}=(3.754,4.334,5.178) \otimes(14.462,17.561,21.344)^{-1}=(0.176,0.247,0.358 ;[17]$

$S_{F_{2}}=(4.946,6.330,7.834) \otimes(14.462,17.561,21.344)^{-1}=(0.232,0.361,0.542)[18]$

$S_{F_{4}}=(2.441,2.691,3.143) \otimes(14.462,17.561,21.344)^{-1}=(0.114,0.153,0.217) \quad[19]$

$S_{F_{3}}=(3.321,4.206,5.189) \otimes(14.462,17.561,21.344)^{-1}=(0.156,0.240,0.359) \quad[20]$

The values of $S_{i}$ are compared, and the degrees of possibility are calculated using Equation (II). Table 3 shows the values of $V\left(S_{i} \geq S j\right)$.

TABLE 3 The values of $V\left(S_{i} \geq S_{i}\right)$.

$\mathrm{V}\left(\mathrm{S}_{\mathrm{F}_{1}} \geq \mathrm{S}_{1}\right)$ Value $\mathrm{V}\left(\mathrm{S}_{\mathrm{F}_{2}} \geq \mathrm{S}_{1}\right)$ Value $\mathrm{V}\left(\mathrm{S}_{\mathrm{F}_{3}} \geq \mathrm{S}_{\mathrm{S}}\right)$ Value $\mathrm{V}\left(\mathrm{S}_{\mathrm{F}_{4}} \geq \mathrm{S}_{\mathrm{S}}\right)$ Value

$\begin{array}{lllllllll}V & V\left(S_{F 1} \geq S_{F 2}\right) & 0.526 & V\left(S_{F 2} \geq S_{F 1}\right) & 1.000 & V\left(S_{F 3} \geq S_{F 1}\right) & 0.961 & V\left(S_{F 4} \geq S_{F 1}\right) & 0.307\end{array}$

$\begin{array}{llllll}V & \left.S_{F 1} \geq S_{F 3}\right) & 1.000 V\left(S_{F 2} \geq S_{F 3}\right) & 1.000 V\left(S_{F 3} \geq S_{F 2}\right) & 0.512 V\left(S_{F 4} \geq S_{F 2}\right) & 0.000\end{array}$

\begin{tabular}{llllll}
$\mathrm{V}\left(\mathrm{S}_{\mathrm{F}} \geq \mathrm{S}_{\mathrm{F}}\right)$ & $1.000 \mathrm{~V}\left(\mathrm{~S}_{\mathrm{F} 2} \geq \mathrm{S}_{\mathrm{F}}\right)$ & $1.000 \mathrm{~V}\left(\mathrm{~S}_{\mathrm{F} 3} \geq \mathrm{S}_{\mathrm{F}}\right)$ & $1.000 \mathrm{~V}\left(\mathrm{~S}_{\mathrm{F} 4} \geq \mathrm{S}_{\mathrm{F} 3}\right)$ & 0.417 \\
\hline
\end{tabular}

The minimum of the degrees of possibility are found as follows:

$$
\begin{aligned}
& d^{\prime}\left(F_{1}\right)=\min (0.526,1.000,1.000)=0.526 \\
& d^{\prime}\left(F_{2}\right)=\min (1.000,1.000,1.000)=1.000 \\
& d^{\prime}\left(F_{3}\right)=\min (0.961,0.512,1.000)=0.512 \\
& d^{\prime}\left(F_{4}\right)=\min (0.307,0.000,0.417)=0.000
\end{aligned}
$$

The weight vector is obtained as $\mathrm{W}=(0.526$, $1.000,0.512,0.000)$. After the normalization process, the weights of the cutting tool properties, machining parameters, wood structure and properties, and cutting phenomena factors are obtained as $0.258,0.49 \mathrm{I}, 0.25 \mathrm{I}$, and 0.000 , respectively. The results obtained for the main factors are compatible with the results of Laina et al. (2017).

The same calculations are applied to the other matrices. The pairwise comparison matrices of the subfactors can be seen from Tables 4-7.
The weights of the factors are summarized in Table 8. The global weight of the subfactor can be computed by multiplying its local weight with its corresponding weight. The global weights calculated for the subfactors are presented in the last column of Table 8.

\section{RESULTS AND DISCUSSION}

In this study, the importance of each factor is determined by employing the FAHP method. The pairwise comparison matrices are obtained through experts' opinions. Then the weights of the factors are calculated. The weights calculated for each factor are summarized in Table 8.

When the weights given in Table 8 are analyzed, it is observed that the highest weighted main factor is machining parameters $(0.49 \mathrm{I})$. Therefore, machining parameters should be considered as the most significant main factor. The subfactor with the highest weight of this main factor is tool geometry $(0.860)$. It is followed by tool sharpness with the weight of 0.140 .

The second highest weighted main factor is cutting tool properties $(0.258)$, and the highest weighted subfactors of this main factor are feed speed $(0.6 \mathrm{II})$ and cutting speed (0. I49). From Table 8, it is clear that feed speed $(0.300)$ is the main factor that significantly influences the surface roughness of wood and wood-based materials in the planing process.

The third highest weighted main factor is wood structure and properties $(0.25 \mathrm{I})$, and the highest weighted subfactors of this main factor are material defect (0.425), density $(0.267)$, and moisture content $(0.246)$. The lowest important degree is allocated to sapwood-heartwood (weight is 0.000 ).

TABLE 4 The comparison matrix of the subfactors within cutting tool properties.

\begin{tabular}{ccccc}
\hline Subfactor & FII & FI2 & FI3 & Weight \\
\hline FII & $(I .000,1.000,1.000)$ & $(4.120,5.207,6.260)$ & $(I .189,1.627,2.213)$ & 0.860 \\
FI2 & $(0.160,0.192,0.243)$ & $(1.000,1.000,1.000)$ & $(0.330,0.435,0.604)$ & 0.000 \\
FI3 & $(0.452,0.615,0.84 I)$ & $(I .655,2.300,3.027)$ & $(I .000,1.000,1.000)$ & 0.140 \\
\hline
\end{tabular}

\begin{tabular}{|c|c|c|c|c|c|c|c|}
\hline Subfactor & F3I & F32 & F33 & F34 & F35 & F36 & Weight \\
\hline $\mathrm{F} 3 \mathrm{I}$ & $(1.000,1.000,1.000)$ & $(0.760,0.955,1.316)$ & $(1.075,1.257,1.565)$ & $(2.000,2.590,3.130)$ & $(0.452,0.604,0.783)$ & $(1.732,2.000,2.236)$ & 0.246 \\
\hline $\mathrm{F} 32$ & $(0.760,1.047,1.316)$ & $(1.000,1.000,1.000)$ & $(1.189,1.565,1.861)$ & $(2.632,3.162,3.663)$ & $(0.427,0.562,0.707)$ & $(1.278,1.495,1.732)$ & 0.267 \\
\hline F33 & $(0.639,0.795,0.931)$ & $(0.537,0.639,0.84 I)$ & $(1.000,1.000,1.000)$ & $(1.316,1.682,1.968)$ & $(0.302,0.435,0.639)$ & $(0.809,1.075,1.316)$ & 0.034 \\
\hline F34 & $(0.319,0.386,0.500)$ & $(0.273,0.316,0.380)$ & $(0.508,0.595,0.760)$ & $(1.000,1.000,1.000)$ & $(0.237,0.319,0.411)$ & $(0.427,0.473,0.537)$ & 0.000 \\
\hline F35 & $(1.278,1.655,2.213)$ & $(1.414,1.778,2.340)$ & $(1.565,2.300,3.310)$ & $(2.432,3.130,4.213)$ & $(1.000,1.000,1.000)$ & $(1.495,1.861,2.432)$ & 0.425 \\
\hline F36 & $(0.447,0.500,0.577)$ & $(0.577,0.669,0.783)$ & $(0.760,0.931,1.236)$ & $(1.861,2.115,2.340)$ & $(0.4 I I, 0.537,0.669)$ & $(1.000,1.000,1.000)$ & 0.028 \\
\hline
\end{tabular}

TABLE 5 The comparison matrix of the subfactors within machining parameters.

\begin{tabular}{cccccccc}
\hline Subfactor & $F 21$ & $F 22$ & $F 23$ & $F 24$ & $F 25$ & F26 & Weight \\
\hline F2I & $(1.000,1.000,1.000)$ & $(1.861,2.913,3.936)$ & $(0.537,0.760,1.107)$ & $(0.343,0.427,0.595)$ & $(0.562,0.841,1.189)$ & $(0.760,1.047,1.316)$ & 0.120 \\
F22 & $(0.254,0.343,0.537)$ & $(1.000,1.000,1.000)$ & $(0.485,0.669,1.057)$ & $(0.193,0.240,0.319)$ & $(0.473,0.639,0.841)$ & $(0.325,0.398,0.537)$ & 0.000 \\
F23 & $(0.904,1.316,1.861)$ & $(0.946,1.495,2.060)$ & $(1.000,1.000,1.000)$ & $(0.316,0.380,0.485)$ & $(1.125,1.612,2.149)$ & $(0.795,1.107,1.607)$ & 0.120 \\
F24 & $(1.682,2.340,2.913)$ & $(3.130,4.162,5.180)$ & $(2.060,2.632,3.162)$ & $(1.000,1.000,1.000)$ & $(2.378,2.943,3.464)$ & $(2.060,2.632,3.162)$ & 0.611 \\
F25 & $(0.841,1.189,1.778)$ & $(1.189,1.565,2.115)$ & $(0.465,0.620,0.889)$ & $(0.289,0.340,0.420)$ & $(1.000,1.000,1.000)$ & $(0.420,0.546,0.748)$ & 0.000 \\
F26 & $(0.760,0.955,1.316)$ & $(1.861,2.515,3.080)$ & $(0.622,0.904,1.257)$ & $(0.316,0.380,0.485)$ & $(1.337,1.831,2.378)$ & $(1.000,1.000,1.000)$ & 0.149 \\
\hline
\end{tabular}

TABLE 6 The comparison matrix of the subfactors within wood structure and properties. 
TABLE 7 The comparison matrix of the subfactors within cutting phenomena

\begin{tabular}{ccccc}
\hline Subfactor & F4I & F42 & F43 & Weight \\
\hline F4I & $(I .000,1.000,1.000)$ & $(0.748,0.904,1.150)$ & $(0.429,0.537,0.727)$ & 0.000 \\
F42 & $(0.869,1.107,1.337)$ & $(1.000,1.000,1.000)$ & $(0.310,0.376,0.500)$ & 0.000 \\
F43 & $(1.375,1.861,2.329)$ & $(2.000,2.659,3.224)$ & $(1.000,1.000,1.000)$ & 1.000 \\
\hline
\end{tabular}

TABLE 8 Summary of the weights

\begin{tabular}{|c|c|c|c|c|}
\hline Main factor & Local weight & Subfactor & Local weight & Global weight \\
\hline $\begin{array}{l}\text { Cutting tool properties } \\
\text { (FI) }\end{array}$ & 0.258 & $\begin{array}{c}\text { Tool geometry (FII) } \\
\text { Type of cutting tool material }(\mathrm{FI} 2) \\
\text { Tool sharpness (FI3) }\end{array}$ & $\begin{array}{l}0.860 \\
0.000 \\
0.140\end{array}$ & $\begin{array}{l}0.222 \\
0.000 \\
0.036\end{array}$ \\
\hline $\begin{array}{l}\text { Machining parameters } \\
\text { (F2) }\end{array}$ & 0.491 & $\begin{array}{c}\text { Number of cutter (F2I) } \\
\text { Cutting angle (F22) } \\
\text { Cutting depth (F23) } \\
\text { Feed speed (F24) } \\
\text { Cutting direction (F25) } \\
\text { Cutting speed (F26) }\end{array}$ & $\begin{array}{l}0.120 \\
0.000 \\
0.120 \\
0.611 \\
0.000 \\
0.149\end{array}$ & $\begin{array}{l}0.059 \\
0.000 \\
0.059 \\
0.300 \\
0.000 \\
0.073\end{array}$ \\
\hline $\begin{array}{l}\text { Wood structure and } \\
\text { properties (F3) }\end{array}$ & 0.251 & $\begin{array}{c}\text { Moisture content (F3I) } \\
\text { Density (F32) } \\
\text { Hardness (F33) } \\
\text { Sapwood-heartwood (F34) } \\
\text { Material defect (F35) } \\
\text { Ring width (F36) }\end{array}$ & $\begin{array}{l}0.246 \\
0.267 \\
0.034 \\
0.000 \\
0.425 \\
0.028\end{array}$ & $\begin{array}{l}0.062 \\
0.067 \\
0.008 \\
0.000 \\
0.107 \\
0.007\end{array}$ \\
\hline $\begin{array}{l}\text { Cutting phenomena } \\
\text { (F4) }\end{array}$ & 0.000 & $\begin{array}{c}\text { Cutting force variation (F4I) } \\
\text { Vibrations (F42) } \\
\text { Chip shape and thickness (F43) }\end{array}$ & $\begin{array}{l}0.000 \\
0.000 \\
1.000\end{array}$ & $\begin{array}{l}0.000 \\
0.000 \\
0.000\end{array}$ \\
\hline
\end{tabular}

The results presented in Table 8 show that the lowest weighted main factor is cutting phenomena (0.000). The ranking of the subfactors of this main factor in descending order with respective weights is chip shape and thickness $(1.000)>$ cutting force variation $(0.000)$ $=$ vibrations $(0.000)$. This ranking result shows that chip shape and thickness is the most important subfactor.

From the last column of Table 8 , it can be concluded that feed speed, tool geometry, and material defect play an important role in enhancing the product quality. The wood industry should focus on the abovementioned factors to improve surface quality. Many researchers have investigated the influence of feed speed on surface roughness. The experimental results have showed that feed speed is the most dominating factor for surface roughness (De Deus et al., 2015; Stanojevic et al., 20I7; Hazir et al., 2018). Several researchers have stated that tool geometry has a large impact on the quality of the machined surface (Sinn et al., 2009; Öhman et al., 2016). On the other hand, previous studies have noted that material defect is the subfactor that significantly influences surface roughness (Sütçü, 2013; Cetiner et al., 2016). Consequently, it can be said that the results of this study are compatible with the literature.

The type of cutting tool material, cutting angle, cutting direction, sapwood-heartwood, cutting force variation, and vibrations are undoubtedly important factors. However, the obtained results indicate that the contribution of these subfactors to surface roughness is less than the other subfactors.

Wood is the basic raw material for the furniture industry. Machining is applied to wood materials to create different geometries and shapes. Surface defects due to a machining process reduce the quality of wood and wood-based products. Therefore, the analysis of factors affecting the surface roughness of wood and wood-based materials is very important. There are many studies about surface roughness. However, the use of the FAHP method to prioritize factors affecting the surface roughness of wood and wood-based materials in planing is a new concept.

The main contributions of the current study are twofold. First, the evaluation of factors influencing the surface roughness of wood and wood-based materials in planing is considered as a complex MCDM problem. Second, this study prioritizes the weights of these factors. The findings of this study are highly important from an industrial viewpoint. Consequently, it can be said that this study presents a route map for further studies on surface roughness.

\section{CONCLUSION}

The objective of this study is to prioritize some factors affecting the surface roughness of wood and wood-based materials in the planing process. Four main factors and eighteen subfactors are analyzed using the FAHP method. The data obtained from the experts are used in the prioritization model to determine the importance of the factors.

According to the prioritization model, the most significant subfactors are feed speed, tool geometry, and material defect. The wood industry should focus on these subfactors to achieve a high quality surface. Consequently, the results obtained in this study can 
provide a useful guide to the wood industry to improve the surface quality of wood and wood-based products. In further research, the findings of this study can be compared with the results of experimental studies.

\section{REFERENCES}

AGUILERA, A. Cutting energy and surface roughness in medium density fiberboard rip sawing. European Journal of Wood and Wood Products, v. 69, n. I, p. II-18, 2011.

AZIZI, M. A model of supplying poplar wood for Iranian paper \& wood factories. Journal of Forestry Research, v. 19, n. 4, p. 323-328, 2008.

AZIZI, M.; MODARRES, M. A decision making model for investment and development of construction panels. Journal of Forestry Research, v. 22, n. 2, p. 30I-310, 201 I.

AZIZI, M.; MOMENI, E.; MOHEBBI, N. Providing a decisionmaking model for importing medium-density fiberboard product. Journal of the Indian Academy of Wood Science, v. 9, n. 2, p. II5-129, 2012.

BEŞIKÇI, E.B.; KECECI, T.; ARSLAN, O.; TURAN, O. An application of fuzzy-AHP to ship operational energy efficiency measures. Ocean Engineering, v. 121, p. 392402, 2016.

BOZBURA, FT.; BESKESE, A.; KAHRAMAN, C. Prioritization of human capital measurement indicators using fuzzy AHP Expert Systems with Applications, v. 32, n. 4, p. I 100 I | | 2, 2007.

BÜYÜKÖZKAN, G.; ÇIFÇI, G. A combined fuzzy AHP and fuzzy TOPSIS based strategic analysis of electronic service quality in healthcare industry. Expert Systems with Applications, v. 39, n. 3, p. 234I-2354, 2012.

BUYUKSARI, U.; AKBULUT, T.; GULER, C.; AS, N. Wettability and surface roughness of natural and plantation-grown narrow-leaved ash (Fraxinus angustifolia Vahl.) wood. BioResources, v. 6, n. 4, p. 472I-4730, $201 \mathrm{I}$.

CETINER, I.; VAR, A.A.; CETINER, H. Classification of knot defect types using wavelets and KNN. Elektronika ir Elektrotechnika, v. 22, n. 6, p. 67-72, 2016.

CHANG, D.-Y. Applications of the extent analysis method on fuzzy AHP. European Journal of Operational Research, v. 95, n. 3, p. $649-655,1996$.

DE DEUS, P.R.; ALVES, M.C.S.; VIEIRA, F.H.A. The quality of MDF workpieces machined in CNC milling machine in cutting speeds, feedrate, and depth of cut. Meccanica, v. 50, n. I2, p. 2899-2906, 2015.

EBADI, M.J.; SULEIMAN, M.; ISMAIL, F.B.; AHMADIAN, A.; BALOOCH SHAHRYARI, M.R.; SALAHSHOUR, S. A new distance measure for trapezoidal fuzzy numbers. Mathematical Problems in Engineering, v. 2013, Article ID 424I86, p. I-4, 2013.
GURLEYEN, L. The study for the strain of hardwood materials against machines and cutters in planning process. Scientific Research and Essays, v. 5, n. 24, p. 3903-3913, 2010.

HAZIR, E.; ERDINLER, E.S.; KOC, K.H. Optimization of CNC cutting parameters using design of experiment (DOE) and desirability function. Journal of Forestry Research, v. 29, n. 5, p. |423-|434, 2018.

HEO, E.; KIM, J.; BOO, K.J. Analysis of the assessment factors for renewable energy dissemination program evaluation using fuzzy AHP. Renewable and Sustainable Energy Reviews, v. 14, n. 8, p. 2214-2220, 2010.

HIZIROGLU, S.; ZHONG, Z.W.; TAN, H.L. Measurement of bonding strength of pine, kapur and meranti wood species as function of their surface quality. Measurement, v. 46, n. 9, p. 3198-3201, 2013.

IŞIKLAR, G.; BÜYÜKÖZKAN, G. Using a multi-criteria decision making approach to evaluate mobile phone alternatives. Computer Standards \& Interfaces, v. 29, n. 2, p. 265274, 2007.

IŞLEYEN, Ü.K.; KARAMANOĞLU, M. The influence of machining parameters on surface roughness of MDF in milling operation. BioResources, v. 14, n. 2, p. 3266-3277, 2019.

KAHRAMAN, C.; KAYA, İ. A fuzzy multicriteria methodology for selection among energy alternatives. Expert Systems with Applications, v. 37, n. 9, p. 6270-6281, 2010.

KARAKUŞ, K.; AYDEMIR, D.; ÖZTEL, A.; GUNDUZ, G.; MENGELOGLU, F. Nanoboron nitride-filled heat-treated wood polymer nanocomposites: comparison of different multicriteria decision-making models to predict optimum properties of the nanocomposites. Journal of Composite Materials, v. 5I, n. 30, p. 4205-4218, 2017.

KILIC, M.; HIZIROGLU, S.; BURDURLU, E. Effect of machining on surface roughness of wood. Building and Environment, v. 4I, n. 8, p. I074-1078, 2006.

KUZMAN, M.K.; GROŠELJ, P. Wood as a construction material: comparison of different construction types for residential building using the analytic hierarchy process. Wood Research, v. 57, n. 4, p. 591-600, 2012

LAINA, R.; SANZ-LOBERA, A.; VILLASANTE, A.; LÓPEZ-ESPÍ, P.; MARTÍNEZ-ROJAS, J.A.; ALPUENTE, J.; SÁNCHEZMONTERO, R.; VIGNOTE, S. Effect of the anatomical structure, wood properties and machining conditions on surface roughness of wood. Maderas. Ciencia y tecnología, v. 19, n. 2, p. 203-212, 2017.

LEE, S.K.; MOGI, G.; LEE, S.K.; KIM, J.W. Prioritizing the weights of hydrogen energy technologies in the sector of the hydrogen economy by using a fuzzy AHP approach. International Journal of Hydrogen Energy, v. 36, n. 2, p. 1897-1902, 20II 
LI, W.; ZHANG, Z.; PENG, X.; LI, B. The influences of circular saws with sawteeth of mic-zero-degree radial clearance angles on surface roughness in wood rip sawing. Annals of Forest Science, v. 74, n. 2, p. 37, 2017.

LIPUŠČEK, I.; BOHANEC, M.; OBLAK, L.; STIRN, L.Z. A multi-criteria decision-making model for classifying wood products with respect to their impact on environment. International Journal of Life Cycle Assessment, v. 15, n. 4, p. 359-367, 2010.

LOPES, C.S.D.; NOLASCO, A.M.; FILHO, M.T.; DIAS, C.T.D.S. Evaluation of wood surface roughness of eucalypt species submitted to cutterhead rotation. CERNE, v. 20, n. 3, p. 47I-476, 2014

LU, C. Study on prediction of surface quality in machining process. Journal of Materials Processing Technology, v. 205, n. I-3, p. 439-450, 2008.

MAGOSS, E. General regularities of wood surface roughness. Acta Silvatica \& Lignaria Hungarica, v. 4, p. 8I-93, 2008.

MALKOÇOĞLU, A. Machining properties and surface roughness of various wood species planed in different conditions. Building and Environment, v. 42, n. 7, p. 2562-2567, 2007.

ÖHMAN, M.; GRUBîl, V.; SANDBERG, D.; EKEVAD, M. Moistening of the wood surface before planing for improved surface quality. Wood Material Science \& Engineering, v. II, n. 3, p. 156-163, 2016.

PINKOWSKI, G.; SZYMAŃSKI, W.; KRAUSS, A.; STEFANOWSKI, $S$. Effect of sharpness angle and feeding speed on the surface roughness during milling of various wood species. BioResources, v. I3, n. 3, p. 6952-6962, 2018.

RAJAK, A.K.; NIRAJ, M.; KUMAR, S. Designing of fuzzy expert heuristic models with cost management toward coordinating AHP, fuzzy TOPSIS and FIS approaches. Sadhana, v. 4I, n. I0, p. I209-I2I8, 2016.

SAATY, T.L. The analytic hierarchy process: planning, priority setting, resource allocation. McGraw-Hill International Book Company, 1980.

SARFI, F; AZIZI, M.; ARIAN, A. A multiple criteria analysis of factors affecting markets of engineered wood products with respect to customer preferences: a case study of particleboard and MDF. Forest Science and Practice, v. I5, n. I, p. 6I-69, 2013.
SINN, G.; SANDAK, J.; RAMANANANTOANDRO, T. Properties of wood surfaces - characterization and measurement. A review. Holzforschung, v. 63, n. 2, p. 196-203, 2009.

SMITH, R.L.; BUSH, R.J.; SCHMOLDT, D.L. A hierarchical model and analysis of factors affecting the adoption of timber as a bridge material. Wood and Fiber Science, v. 27 , n. 3, p. 225-238, 1995.

STANOJEVIC, D.; MANDIC, M.; DANON, G.; SVRZIC, $S$. Prediction of the surface roughness of wood for machining. Journal of Forestry Research, v. 28, n. 6, p. $|28|-\mid 283,2017$.

SÜTÇÜ, A. Investigation of parameters affecting surface roughness in CNC routing operation on wooden EGP. BioResources, v. 8, n. I, p. 795-805, 2013.

TAN, P.L.; SHARIF, S.; SUDIN I. Roughness models for sanded wood surfaces. Wood Science and Technology, v. 46, n. I-3, p. I29-|42, 2012.

TIRYAKI, S.; HAMZAÇEBI, C.; MALKOÇOĞLU, A. Evaluation of process parameters for lower surface roughness in wood machining by using Taguchi design methodology. European Journal of Wood and Wood Products, v. 73, n. 4, p. 537 $545,2015$.

TIRYAKI, S.; ÖZŞAHIN, Ş.; AYDIN, A. Employing artificial neural networks for minimizing surface roughness and power consumption in abrasive machining of wood. European Journal of Wood and Wood Products, v. 75, n. 3, p. 347-358, 2017.

TSAI, K.M.; CHOU, F.C. Developing a fuzzy multi-attribute matching and negotiation mechanism for sealed-bid online reverse auctions. Journal of Theoretical and Applied Electronic Commerce Research, v. 6, n. 3, p. 85-96, $201 \mathrm{I}$.

UGULINO, B.; HERNÁNDEZ, R.E. Assessment of surface properties and solvent-borne coating performance of red oak wood produced by peripheral planing. European Journal of Wood and Wood Products, v. 75, n. 4, p. $581-593,2017$

ULKER, O. Surface roughness of composite panels as a quality control tool. Materials, v. II, n. 3, p. 407, 2018.

ZADEH, L.A. Fuzzy sets. Information and Control, v. 8, n. 3, p. 338-353, 1965. 